\title{
STIMULATING YOU TO SPEAK; A STRIP STORY AS A TECHNIQUE IN TEACHING SPEAKING
}

\author{
Abdul Aziz Rifa'at \\ STIK Siti Khadijah Palembang \\ aziz_lie2@yahoo.co.id
}

\begin{abstract}
A strip story is one of the techniques that could stimulate the students to speak during the learning process especially in speaking class. The aim of this study was to find out the significance difference of students' speaking achievement after they were taught by using strip story technique. The pre experimental study was the method of the study. The one group pretest-posttest design approach was used in this study. The study was conducted to sixth semester S1 Nursing students at STIK Siti Khadijah Palembang. The population of the study was all fourth semester S1 Nursing students at STIK Siti Khadijah Palembang in 2018. The total number of the population was 69 students. The sample of the study was 22 fourth semester S1 Nursing students at STIK Siti Khadijah Palembang in 2018. Systematic sampling was used to collect the sample. The test was administered twice as pre-test and post-test. The results of the tests were analyzed by using t-test through SPSS (Statistical Package for Social Sciences) program. The result of the study showed that there was a significant difference in speaking achievement before and after applying strip story technique based on paired sample t-test.
\end{abstract}

Keywords: speaking, strip story

\begin{abstract}
Abstrak
Strip story adalah sebuah teknik yang dapat merangsang pelajar untuk berbicara selama proses pembelajaran khususnya dalam kelas Speaking. Tujuan dari penelitian ini adalah untuk mencari perbedaan yang signifikan dalam pencapaian kemampuan berbiacra setelah mereka diajarkan menggunakan teknik strip story. Preeksperimental adalah metode dalam penelitian ini. Pendekatan yang digunakan adalah one-group pre-test post-test. Penelitian ini dilakukan terhadap mahasiswa semester 6 program studi S1 Keperawatan diSTIK Siti Khadijah Palembang pada tahun 2018. Jumlah populasi dalam penelitian ini adalah 69 mahasiswa. Sampel dalam penelitian ini berjumlah 22 mahasiswa semester empat program studi S1 Keperawatan STIK Siti Khadijah Palembang tahun 2018. Teknik pengambilan sampel meggunakan teknik sistematik. Tes diberikan dua kali berupa pre-test dan post-test. hasil penelitian
\end{abstract}


dianalisa menggunakan t-test dengan program SPSS. Hasil dari tes menunjukkan bahwa terdapat perbedaan yang signifikan dalam pencapaian kemampuan berbicara sebelum dan sesudah diterapkan strip story berdasarkan paired sample t-test.

Kata Kunci: percakapan, cerita acak

\section{A. Introduction}

There are many ways to communicate and one of them through speaking. Speaking is an interactive process of constructing meaning that involves producing, receiving, and processing information (Brown, 1994). Speaking is the tool for communication between two or more people. People need to speak to deliver the information to the listener.

Among the four skills in English, Speaking seems to be the most important skill to be learned. Sarosdy, Bencze, Poor and Vadnay (2006) state that of all the four simplex skills (listening, reading, speaking, writing) speaking seems to be the most important as people who know a language are referred to as 'speakers' of that language, as if speaking included all other kinds of knowing a language. In Indonesia English is known as a foreign language. There are a few of people speak English as their daily language. This is the main point; people sometimes avoid speaking in English because it has not become accustomed to be spoken as long as it is foreign language.

Many countries in southern of Asia such as Philippine, Singapore, and Malaysia use English as a second language not a foreign language so that the people are accustomed to speak in English. In Indonesia especially in Palembang city, English are taught in the classroom from junior high school to senior high school and continued to university level. However, the language of instruction is still Bahasa except in English major. Only a few of junior and senior high school apply English as the language instruction in Palembang city. Those "special" schools are categorized as high class level schools.

STIK Siti Khadijah as one of high schools in Palembang city also has English subject that is given at least 2 credit hours for every major. Especially in S1 Keperawatan, English is taught 8 credit hours. The skill that hardly paid attention is speaking skill. Students in this institution will be produced as professional nurse that might work in many clinics and hospitals. It is not impossible that they are required to be able to communicate in English because Indonesian President has been launched the ASEAN Economic Community or AEC and also Industrial Revolution 4.0. This condition indirectly forces the people including students in Indonesia to be able to speak in English. 
Students at STIK Siti Khadijah have a big problem in exploring their ability in English especially in speaking skill. Feeling shy, afraid of having mistakes and lacking of vocabularies are the reason why this problem appears. Some of them are actually able to respond when they are asked to respond in English but not all of them. Only a few of them could respond when they are involved in communication with English. There are some factors that correlated to this situation. The students at STIK Siti Khadijah come from different small villages and have different educational backgrounds. Those two possible factors sometimes affect the process of teaching and learning. The pronunciation, vocabularies, or skills could be influenced by those factors. The lecturers at STIK Siti Khadijah need to vary the techniques in teaching English to find the best technique for the students.

A strip story is one of the techniques that could be a better solution for this problem. Freeman (2000) states that there are some materials and techniques associated with CLT, they are authentic materials, scrambled sentences, language games, picture strip story, and role play. Strip story itself has some advantages. This technique could "force" the students to talk even some of them might be memorize some words that should be told. This technique also makes the classroom situation very fun. The students can explore their languages ability, in this case speaking skill, by telling the story.

Prawerti (2015) in her research states that Related to the teaching speaking, Strip Stories technique has some advantages. They are as follows: (1) The strip story activity provides a fun and useful way of introducing new texts and/or new vocabulary and grammatical items; (2) Strip stories give students an opportunity to speak up freely. It also helps students to develop ideas to speak/ retelling the story; (3) It also brings good impact on increasing the learning process and they can work not only individually but also in a group; (4) In the strip stories activity, the students speak with occasional hesitation, use adequate vocabulary, use comprehensible pronunciation, and use complex sentence in asking and responding. Most of the students started to speak more bravely and without feeling shy anymore.

Furthermore, she adds that The use of strip stories technique also has its disadvantages as described below; (1) It spends time to organize and understand the students; (2) The writer must have a will to spend her own spare time at home for searching the suitable materials. In this case, the teacher should prepare additional time to get some appropriate materials before giving the treatment.

According to Gebhard cited in Prawerti (2015) in applying the Strip Stories Technique in the classroom, there some steps that should be implemented in the teaching and learning activities in general as follows : 1) Pre - activity. Before the 
main activity in Strip Story technique, it is helpful to activate the background knowledge that the student have and to prepare them for new vocabulary and grammatical structure they are going to encounter in the text. To do so, the teachers can use the activity likes 'Vocabulary Bingo' or they write down the vocabularies in to the whiteboard and discuss together with the students; 2) During - activity. It is the main activity in using Strip Story Technique. The Strip Story activity is done by the students in a group. The stages of speaking activity by using strip story technique as like stated by Gebhard, such as; (a) The students are put into small groups and given one or two lines of short story; (b) They are told not to show their lines to other students to put the story together; (c) They have to negotiate who has the fi rst line, second line, and so on; (d) An alternative way is take the strips away and having the students put the story together from memory. The other variation of Strip Story activity that can be used by the teacher is as follow: (a) First, the teacher and the students decide the groups and also the members of the groups; (b) Second, the teacher distributes the strips to the students; (c) Third, the teacher gives students time to read the strips and comprehend the sentences; (d) Fourth, the students have to comprehend it, hand-writing is not allowed here; (e) Fifth, the teacher collects the strips from each student; (f) Sixth, each student have to retell what they already understood from their strip to their friends, then they discuss and works out how the strips should be assembled to form the correct sequence of the story through oral communication; (g) Finally, they have to present their discussion in front of the class 3) Post - activity. In the post - activity is giving feedback from the teacher to the students. The feedback is about the activity that they have already done before. 6 The Teacher's Considerations in using Strip Story Activity as follow; (a) Choice of story (or other suitable text); (b) Choose a story or sequenced text that is appropriate for your students, for example, a legend, recipe; (c) It should be one that students have not heard before (except if you need to make the task easier); (d) It should have words and grammar that the students already know; (e) Students must only read their own sentence, and not read the sentences distributed to other students; (f) The teacher does not take part in the activity, but may prompt suitable phrases for the students to use to negotiate with each other.

Lavery (2011) asserts picture strip story can be used from beginners level to advanced level for a variety of language and discussion activities. The students could express their ideas, combined with the text or visual information. Picture strip story could create students` confidence to communicate with others, because students memory was stronger than before directly it caused by the picture or images in the narrative text. This technique prepared a chance for students to develop their 
understanding and remembering by the image or picture that written in the text. Additionally, Wright (2004) states that speaking is a productive skill and picture can often be used in similar ways to promote it. It means that strip story as a technique teaching could be an alternative ways in teaching English.

In line with the background of the study above, the problem in this study that must be solved is: was there any significant difference in speaking achievement after they are taught using strip story technique. Furthermore, the objective of the study was to find out whether strip story technique can improve the students' speaking ability after they were taught by using this technique.

\section{B. Research Method}

This study was a pre-experimental design through one group pretest-posttest design approach. The writer used speaking test to collect the data. It was distributed twice as a pre-test and post-test. The pre-test was given to the sample students before treatment and the post-test was given after treatment. The schema of one group pre test-post test design is shown as figure 1 below (Fraenkel and Wallen, 2008):

$\begin{array}{crr}\text { Pre-test } & \text { Treatment } & \text { Post-test } \\ \mathrm{O} & \mathrm{X}\end{array}$

Note: $\mathrm{X}$ is the treatment that given to the sample study through strip story

Figure 1. One Group Pretest-Posttest Design.

The population of the study was all fourth semester S1 Nursing students at STIK Siti Khadijah Palembang in 2018. The total number of the population was 69. The sample of the study was 22 fourth semester S1 Nursing students at STIK Siti Khadijah Palembang in 2018. Systematic sampling was used to collect the sample. There were three stages in analyzing the collected data. They were scoring the tests, finding the means of each group and comparing the means. The writer scored the students based on the test that given as pre-test and posttest. After scoring the students tests, the writer categorized the scores based on its interval. The students who got the scores from 25 to 30 were considered as Excellent, who got the scores 19 to 24 were considered as Good, who got 13 to 18 were considered as Fair, and who got 12 were considered as Poor. The oral storytelling rubric was used to score the students' test. Finally, the writer analyzed the students' score by using paired sample t-test through SPSS (Statistical Program for Social Sciences) 


\section{Findings and Discussion}

\section{Findings}

Since an approach of this study was one group pre-test and post-test design, the pre-test and post-test were given before and after the treatment to the experimental group. The pre-test was given at the first meeting before the writer conducted the treatment. The post-test was given at the final meeting after the writer conducted the treatment. The result of the test was presented in form of table 1 and table 2 .

\begin{tabular}{|c|c|c|c|c|c|c|c|c|}
\hline \multirow[t]{2}{*}{ No } & \multirow[t]{2}{*}{ SI } & \multicolumn{6}{|c|}{ Aspect scored } & \multirow[t]{2}{*}{$\mathrm{TS}$} \\
\hline & & $\mathrm{V}$ & $\mathrm{EC}$ & $\mathrm{FE}$ & $\mathrm{BL}$ & VD & $\mathrm{C}$ & \\
\hline 1 & A & 2 & 1 & 1 & 1 & 1 & 2 & 8 \\
\hline 2 & $\mathrm{~B}$ & 2 & 2 & 2 & 1 & 2 & 2 & 11 \\
\hline 3 & $\mathrm{C}$ & 1 & 2 & 1 & 1 & 2 & 2 & 9 \\
\hline 4 & $\mathrm{D}$ & 2 & 2 & 2 & 2 & 2 & 2 & 12 \\
\hline 5 & $\mathrm{E}$ & 2 & 2 & 2 & 1 & 2 & 2 & 11 \\
\hline 6 & $\mathrm{~F}$ & 1 & 2 & 1 & 1 & 2 & 1 & 8 \\
\hline 7 & $\mathrm{G}$ & 2 & 2 & 1 & 1 & 2 & 1 & 9 \\
\hline 8 & $\mathrm{H}$ & 2 & 2 & 2 & 2 & 1 & 1 & 10 \\
\hline 9 & $\mathrm{I}$ & 1 & 1 & 1 & 2 & 2 & 1 & 8 \\
\hline 10 & $\mathrm{~J}$ & 3 & 2 & 2 & 2 & 2 & 2 & 13 \\
\hline 11 & $\mathrm{~K}$ & 2 & 2 & 2 & 2 & 2 & 3 & 13 \\
\hline 12 & $\mathrm{~L}$ & 2 & 2 & 2 & 2 & 1 & 2 & 11 \\
\hline 13 & $\mathrm{M}$ & 1 & 1 & 2 & 1 & 2 & 1 & 8 \\
\hline 14 & $\mathrm{~N}$ & 2 & 3 & 3 & 3 & 3 & 1 & 15 \\
\hline 15 & $\mathrm{O}$ & 1 & 1 & 1 & 1 & 2 & 2 & 8 \\
\hline 16 & $\mathrm{P}$ & 2 & 2 & 2 & 2 & 1 & 1 & 10 \\
\hline 17 & $\mathrm{Q}$ & 2 & 2 & 2 & 2 & 2 & 2 & 10 \\
\hline 18 & $\mathrm{R}$ & 2 & 2 & 1 & 1 & 2 & 1 & 9 \\
\hline 19 & $\mathrm{~S}$ & 1 & 2 & 2 & 2 & 2 & 1 & 10 \\
\hline 20 & $\mathrm{~T}$ & 2 & 2 & 2 & 2 & 2 & 2 & 12 \\
\hline 21 & $\mathrm{U}$ & 1 & 2 & 2 & 2 & 2 & 1 & 10 \\
\hline 22 & $\mathrm{~V}$ & 2 & 2 & 2 & 2 & 2 & 2 & 12 \\
\hline
\end{tabular}

Table 1. Score of pre-test 


\begin{tabular}{|l|l|l|l|l|l|l|l|l|}
\hline \multirow{2}{*}{ No } & \multirow{2}{*}{ SI } & \multicolumn{7}{|c|}{ Aspect scored } \\
\cline { 3 - 8 } & & V & EC & FE & BL & VD & C & \\
\hline 1 & A & 3 & 2 & 1 & 1 & 2 & 2 & 11 \\
\hline 2 & B & 2 & 2 & 2 & 2 & 2 & 3 & 13 \\
\hline 3 & C & 2 & 2 & 2 & 2 & 2 & 3 & 13 \\
\hline 4 & D & 3 & 2 & 2 & 2 & 2 & 3 & 14 \\
\hline 5 & E & 2 & 2 & 2 & 1 & 2 & 2 & 11 \\
\hline 6 & F & 2 & 2 & 2 & 2 & 2 & 2 & 12 \\
\hline 7 & G & 3 & 2 & 3 & 1 & 2 & 3 & 14 \\
\hline 8 & H & 3 & 2 & 2 & 2 & 1 & 2 & 12 \\
\hline 9 & I & 2 & 1 & 1 & 1 & 1 & 1 & 7 \\
\hline 10 & J & 3 & 3 & 3 & 3 & 4 & 4 & 20 \\
\hline 11 & K & 2 & 2 & 2 & 2 & 3 & 3 & 13 \\
\hline 12 & L & 2 & 2 & 2 & 2 & 1 & 2 & 11 \\
\hline 13 & M & 1 & 2 & 1 & 2 & 1 & 1 & 8 \\
\hline 14 & N & 3 & 3 & 3 & 3 & 3 & 4 & 19 \\
\hline 15 & O & 2 & 2 & 2 & 1 & 2 & 2 & 11 \\
\hline 16 & P & 2 & 2 & 3 & 3 & 2 & 2 & 14 \\
\hline 17 & Q & 2 & 2 & 2 & 2 & 2 & 2 & 10 \\
\hline 18 & R & 3 & 2 & 2 & 2 & 2 & 2 & 13 \\
\hline 19 & S & 2 & 2 & 2 & 2 & 2 & 2 & 12 \\
\hline 20 & T & 3 & 2 & 2 & 2 & 2 & 3 & 12 \\
\hline 21 & U & 2 & 2 & 2 & 2 & 2 & 3 & 11 \\
\hline 21 & V & 4 & 2 & 2 & 2 & 2 & 3 & 15 \\
\hline
\end{tabular}

Table2. Score of post-test

Notes:

SI : students' initial

$\mathrm{V}$ : Volume

EC : eye contact

$\mathrm{FE}$ : facial expression

$\mathrm{BL}$ : body language

VD : voice and delivery

C : content

TS : total score

The students' score then categorized as below:

\begin{tabular}{|l|l|}
\hline \multicolumn{1}{|c|}{ Score Range } & \multicolumn{1}{c|}{ Category } \\
\hline $25-30$ & Excellent \\
\hline $19-24$ & Good \\
\hline $13-18$ & Fair \\
\hline $0-12$ & Poor \\
\hline
\end{tabular}

Table 3. Students' range score and category 
The result of pre-test in the experimental group showed that the lowest score was 8 and the highest score was 15 . The mean score was 10.3 and standard deviation was 1.93 . The result of the post-test in the experimental group showed that the lowest score was 7 and the highest score was 20 . The mean score was 12.5 with standard deviation was 3.93. Moreover, the output showed that the correlation between pre-test and post-test in the experimental group was 0.712 and the significant level was 0.00 . Since 0.00 was lower than alpha value 0.05 , it was inferred that the strip story technique was effective. The results of both pre-test and post-test in the experimental groups were analyzed by using paired sample t-test. The analysis was done by using SPSS (Statistical Package for Social Science) program.

\section{Discussion}

The data showed that there was progress from the total scores of pre-test to post-test in the experimental group. The progress can be seen from the diagram bellow:

Figure 2: the diagram of students' progress from pre-test to post-test

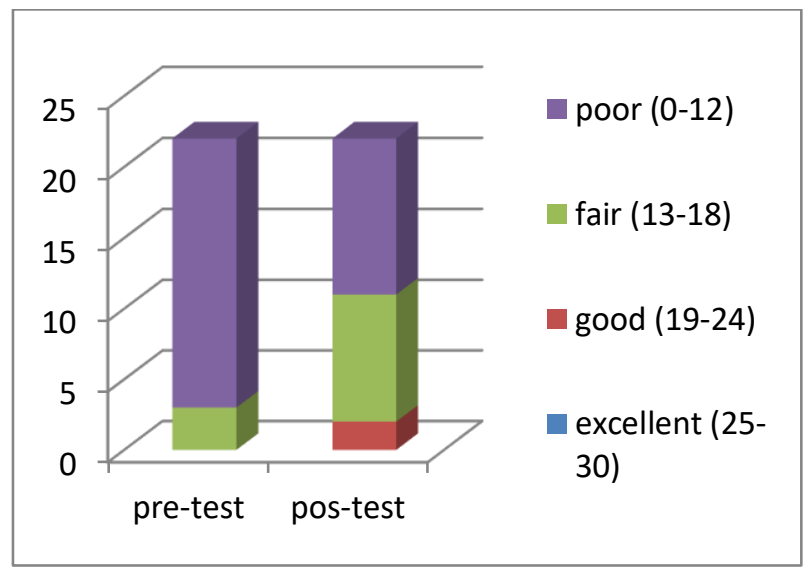

Figure 2. Students' progress

The data from the pre-test showed that there were 19 students at the poor category, 3 students at the fair category, and no student at good category nor excellent. After the students were given treatment trough storytelling approach, the post-test was given. The data showed that there were only 11 students at the poor category, there were 9 students at the fair category, there were 2 students at the good category, and there was no student at the excellent category. 
From those result, it was found that there was one student got lower score in the post-test than in the pre-test. The reason was because the student rarely joins the treatment. It could influence her post-test score. While in the pre-test she got 8 and in the post-test she got 7. However, as an English lecturer at at STIK Siti Khadijah, the writer gives some advices and supports to all of the students and especially to her to be more focus to study.

Additionally, there were some factors that possibly influence this progress. The factors could be from external factors or internal factors. Such factors were the students' participation of local English course out of institution, students' pretention to upgrade the English skill, and so on. Some of the students also sometimes try to learn individually through online learning, group discussion, and so on.

\section{Conclusions}

There were some conclusions in this study. First, there was a significant difference in speaking achievement of fourth semester S1 Nursing program students at Siti Khadijah Palembang after implementing strip story technique. The students got a better score after implementing strip story technique. It can be seen from the students score on the pre-test and their score on the post-test. In relation to these conclusions, the factors above might influence student's speaking scores or in another way it could be said that there could be some external variables that influence students' progress.

\section{References:}

Brown, H. Douglas. 1994. Principles of Language Learning and Teaching, London, Longman.

Freeman, D. L. (2000). Techniques and Principles in Language Teaching (2nd ed). New York: Oxford University Press.

Fraenkel, Jack R. and Norman E. Wallen. 2008. How to Design and Evaluate Research in Education. New York: McGraw-Hill.

Kosdian, O. (2016). Improving Students' Speaking Skill by Using Picture Strip Story. Indonesian EFL Journal, 2(2), 100-109

Lavery, C. 2011. Using Cartoons \& Comic Strips. London : British Council. http://www.teachingenglish.org.uk/language-assistant/teaching tips/usingcartoons-comic-strips. Retrieved on 16 june 2014. 
Prawerti R Candraning. 2015. The effectiveness of Using Strip Stories Technique in Teaching Speaking toward Students' Speaking Achievement. Universum Jurnal KeIslaman dan Kebudayaan, 9(2), 255-264.

Sarosdy, J., Bencze, T. F., Poor, Z., \& Vadnay, M. 2006. Applied linguistics I for BA Students in English. Budapest, Hungary: Bölcsész Konzorcium.

Widiati, U., \& Cahyono, B. Y. 2006. The Teaching of EFL Speaking in the Indonesian Context: The state of the art. BAHASA DAN SENI, 34(2), 269-292.

Wright, A. 2004. Pictures for Language Learning. New York: Cambridge University Press.

Wulandari T, Sukirlan M, \& Suka R Ginting. 2014. Developing Students' Speaking Ability by Using Picture Strip Story. U-JET 3(7) 